\title{
THE VALUE OF BALI'S LOCAL WISDOM ON HOTEL EMPLOYEES IN BADUNG REGENCY
}

\author{
Made Arya Astina \\ Institut Pariwisata dan Bisnis Internasional. Indonesia \\ aryaastina.made@gmail.com
}

\begin{abstract}
The island of Bali is famous as one of the most popular tourist destinations in the world. Thus, the development of Bali tourism from year to year is strongly influenced by various factors. Culture becomes an important factor for tourists choosing Bali as their preferred tourist destination. In order to support the tourism, the human resource also becoming the significant aspect that need to be taken into account. Given the importance of the role of human resources in the tourism sector, especially in the hospitality subsector, this study analyzed the value of Bali's local wisdom among star hotels in Badung regency. this study also wanted to find out how the phenomenon of local wisdom value in Bali, especially in Badung regency. Identification of the value of local Balinese wisdom is expected to gain contribution of ideas and thought in human resource development to the hospitality subsector in Bali in general, and Badung Regency in particular. Through literature studies and questionnaire consisted of 34 questions to measure the six cultural dimension such as Power Distance, Individualism vs. Collectivity, Masculinity vs. Femininity, Uncertainty Avoidance, Long-term orientation vs. Short-term orientation, and Indulgence vs. Restraint, the data then analysed through the VSM (value survey module) developed. The results shows that Badung regency's star hotels' employees have a culture with a high level of collectivism, shows a low power distance value, tend to have Feminine culture, have a culture with a relatively low level of Uncertainty Avoidance
\end{abstract}

Keywords: tourist destination, human resources, local wisdom, cultural dimensions

\section{INTRODUCTION}

The island of Bali is famous as one of the most popular tourist destinations in the world. The enchantment of beauty that could be witnessed from the island led it to be referred as a "tourism paradise" because of its geographical location, unique culture, and social conditions in which the majority of the population is Hindu, while nationally, Hindus become a minority (Picard, 1992). Bali also offers a variety of options and facilities to support leisure activities for visiting tourists. Various fascinating objects are ready to pamper the eyes that became an international tourism icon. The beauty of its beaches, rice fields, and the cultural peculiarities of the local community support the development of the hospitality industry 
The development of Bali tourism from year to year is strongly influenced by various factors. Culture becomes an important factor for tourists choosing Bali as their preferred tourist destination. Famous for the cultural diversity owned by its people, the concept of Bali tourism is also referred to as culture-based tourism or often called Bali Cultural Tourism. This statement is in line with law no. 2 of 2012 on Tourism Culture developed in Bali and regulated in the Provincial Regulation. Customary, arts, and culture of Bali are sources of economic producers in hospitality industry activities. In the basic activities of this industry, it is implied that there is a good and positive reciprocal relationship between tourism and culture. This relationship is expected to be able to support various tourism sector activities to operate to its peak level.

In addition to these things, we cannot ignore the role of tourism actors in Bali in conducting the promotions. The promotions were conducted both offline and online with information technology-based so that the interest of tourists to visit is expected to be high constantly. Thus, information technology plays a huge role in the future development of Bali's cultural tourism.

Generally, Bali's tourism industry is growing positively from year to year. In addition, the number of tourism support facilities in this area continues to grow which positively influence the quality of tourism as well. Hotels as one of the tourism businesses in the accommodation provider sector continue to grow following the number of tourists visiting on vacation. From the statistics, it can be seen that the percentage of foreign tourists visiting Bali as the main tourist destination in Indonesia continues to increase.

Table 1.1

The percentage of the increase of foreign tourist visit to Bali

\begin{tabular}{|l|l|l|l|l|l|l|}
\hline 1 & Year & 2014 & 2015 & 2016 & 2017 & 2018 \\
\hline 2 & Percentage & $14.89 \%$ & $6.24 \%$ & $23.14 \%$ & $15.62 \%$ & $6.54 \%$ \\
\hline
\end{tabular}

(Source: BPS of Bali Province,2019)

The development of tourism industry for decades in The Province of Bali is certainly inseparable from the significant role of its tourism actors. As Evans, Campbell, \& Stonehouse (2003) said that human resources are one of the factors that plays an important role in advancing the tourism sector. Human resources in the tourism sector are a key factor. People are a very crucial resource in most organizations, especially in service-based organizations. Human resources serve as a core factor in achieving the success of an organization's performance.

Bali province has Badung Regency as a tourist destination that is well known by foreign and domestic tourists. Tourism potential in every villages, in Badung Regency provides considerable support to tourism industry activities in general in Bali. This is because some places in Badung Regency have been becoming an iconic tourist destination and a must visit, such as Canggu, Seseh, Plaga. Various activities carried out by these tourist attractions make the Badung 
Regency area continues to grow and offers a variety of opportunities for workers and stakeholders from various sectors supporting the tourism industry.

Badung Regency is also famous as a center of Balinese arts and culture. Badung Regency tourism area is geographically included in the Badung Regency Government. Moreover, Districts that have the most accommodation businesses, restaurants, attractions and become the largest regent that provide contribution economically.

The development of tourism industry in this area is also followed by the development of the number of accommodation facilities and other tourism supporting facilities. From year to year, the number of workers in the tourism sector in Badung Regency continues to grow. They come from various regencies in Bali, even from various provinces in Indonesia. They settled and mingled with the local community, (e.g. in Badung Regency, Bali) making a living and contributing to the tourism industry.

Given the importance of the role of human resources in the tourism sector, especially in the hospitality subsector, this study analyzed the value of Bali's local wisdom among star hotels in Badung regency. The basis of this research is the Hofstede research (2010) which examines the cultural value of a region in Brazil. Inspired by the research of Hofstede et al. in 2010, this study also wanted to find out how the phenomenon of local wisdom value in Bali, especially in Badung regency. Identification of the value of local Balinese wisdom is expected to gain contribution of ideas and thought in human resource development to the hospitality sub-sector in Bali in general, and Badung Regency in particular

Based on the background description above, they are several problem formulation in this study as follows:

1. How the application of local wisdom value applied toward star hotels in Badung Regency?

2. What are the positive impacts of applying local wisdom values to employees at star hotels in Badung Regency?

Considering that Bali Province relies on tourism sector as the main income of its region, then this research is considered significant to be conducted because (1) identification of the application of local wisdom value of star hotels needs to be perfomed as a strategy of employee competency development, (2) employee management based on the right cultural value then the company (hotel) will be able to provide coaching and employee development so that this can be a competitive advantage for the hotel where they works, and (3) improving the quality of service will have an impact on improving the competitiveness of tourism in a region.

Research on the cultural value of human resources in an area with the Hofstede theory has been widely done by researchers. This effort continues in line with the emergence of various phenomena and ideas for human resource development in the tourism sector.

Huang (2019) in his research entitled Relationships between Hofstede's cultural dimensions and tourist satisfaction: A cross-country cross-sample 
examination suggests that culture has been considered to influence tourist behavior but because of the difficulty of measuring cultural values directly at the individual level, the relationship between national culture and visitor satisfaction has still not been empirically proven.

Huang's research used two samples of international tourists, namely the 2017 International tourist holiday sample from Tourism Research Australia 2017 and a sample of the Hong Kong Tourist Satisfaction Project 2016, to test the relationship between the six dimensions of Hofstede culture (Power Distance, Individualism/Collectivism, Masculinity/Femininity, Uncertainty Avoidance, Long Term Orientation/Short Term Normative Orientation, and Indulgence/Restraint) and visitor satisfaction.

The correlation of bivariate with bootstrap tests showed a consistent correlation between four of the six cultural dimensions and visitor satisfaction in both samples. While Individualism and Indulgence were found to be positively associated with visitor satisfaction, Power Distance and Individualism/Collectivism were negatively associated with visitor satisfaction. These findings were validated with further tests involving the concept of cultural distance. This research contributes to the literature by providing strong evidence of the relationship between culture and visitor satisfaction.

Similar research was conducted by Mazanec (2015) in his research entitled Homogeneity versus heterogeneity of cultural values: An item-response theoretical approach applying Hofstede's cultural dimensions in a single nation. There are three main focus of this study such as: first, he tested the validity and reliability of a scale designed to measure the five dimensions of Hofstede culture at an individual or psychological level in two large samples $(n>500)$ of the U.S. population. Once considered the right size, the scale is applied to the question that tests the homogeneity of the action. The questions refer to the speed of acculturation occurring in immigrant populations and the extent to which regional geographic differences are of different cultural values measured by Hofstede.

Bearden (2006) in his research entitled Multidimensional versus unidimensional measures in assessing national culture values: The Hofstede VSM 94 which states that in the national cultural literature has been given on the question of sociological application, group-level measures for psychological phenomena, individual level. A recent study addressed this measurement issued by examining the most widely used measure of national cultural value: developed by Hofstede and his colleagues using the Value Survey Module (VSM) and the updated version, VSM 94.

The Hofstede state-level index score was applied by some researchers at the individual level, which was never intended to be used on the index. Thus, the unidimensional aspects of this index fail to represent the multidimensional nature of individual cultural values. The study involved two major studies, including data collected from more than 1,400 subjects in four countries.

\section{Theoretical Foundation}

This study employs 6 (six) cultural values in accordance to the value survey module presented by Hofstede (2010). Those cultural values could be exaplained as follows: 
a. Power Distance Index (small versus large) measures the extent to which members of an organization/institution that do not have the power to accept that there is an injustice of the distribution of power in the organization/ institution. This dimension reflects the value of members of society who lack power. Countries that show a high-power distance have superiors who can exert power (using power) and the gap between superiors and subordinates remains open. In this culture, subordinates are reluctant to question superior's decisions or disagree. Conversely, countries with low power distances show equal relations between superiors and subordinates. Subordinates are rarely afraid and question to be disagree with their superiors.

b. Uncertainty Avoidance (weak versus strong) measures the extent to which people feel threatened by uncertain, unknown, ambiguous, and unstructured situations. Society can accept an uncertain future or try to avoid it. The nature of this uncertainty is subjective and is judged by the opinions of others about violating organizational rules and their willingness to leave the organization.

c. Individualism versus Collectivism. Individualism is the tendency of society to pay attention to one's own and those close relatives (spouse, child, parents). Individualistic cultures show a more selfish tendency and emphasize on individual goals. Individualistic culture emphasizes job success and achievement or wealth and career progression. Individualists emphasize the importance of personal time aspects and work-related challenges. Collectivism is the tendency of the community to join groups and then take care of each other with the consequences of loyalty exchanges between members.

d. Masculinity versus Feminity. Masculinity reflects a situation where the dominant values in society are "success, money and possessions". Masculine society emphasizes the importance of assertiveness and competition (income, awards/recognition, progress/promotion, and challenges in the work environment). Feminity reflects a society that has dominant values of caring for others, harmony, and tranquillity in life. This culture considers quality of life and the importance of helping others.

e. Long-Term Orientation versus Short-Term Orientation is a development of Hofstede and Bond research (1988) that produced the dimension "Confucian Dynamism". This dimension was later renamed to long-term orientation. People with long-term orientation foster values related to future rewards, such as persistence and austerity. People with short-term orientations foster more values related to the past and present, such as respect for tradition, saving one's self-esteem, and fulfilling social obligations. 
f. Indulgence versus Restraint. Indulgence reflects a society that in its social order strongly tolerates the expression of desires and feelings, especially with regard to the utilization of leisure time, seeking entertainment with friends,

\section{METHODOLOGY}

This research was conducted in Badung Regency. The research period was conducted in June 2020-August 2020. A star hotel in Badung Regency was the specified research subject. The research location was chosen with consideration that tourist in Badung Regency is one of the main tourist destinations that develop relatively quickly. In addition, the tourism workers, especially in the hospitality subsector, in this area are quite large. Therefore, the culture owned by star hotels in Badung Regency needs to be analysed for its product development (service).

There are two common techniques used to collect data, namely literature studies and questionnaires. Thus, these two techniques could be explained as follows: Literature study techniques are the whole effort to obtain books, literature, texts, data through libraries or archives.

This library technique is also known as library research because it is completed in libraries or desk research because it is in principle done on the table as opposed to field research (Sugiyono, 2020). Many library materials comes from books, texts, journal articles, and other similar materials obtained from campus, public, and private libraries. In addition, several material are also obtained from the Internet.

In this study, questionnaire was also applied in the data collection technique. Questionnaires are used for data collection by providing a set of questions or written statements to respondents for them to answer. The determination of informants in this study was conducted purposively, i.e. informants are determined based on certain characteristics and traits that are considered to be related and adapted to the objectives in the study. According to Creswell (2015), purposive sampling means researchers choose individuals and places to research because they can specifically provide an understanding of research problems and phenomena in the study.

In this study, spread out questionnaires was employed that had been developed by Hofstede using the Likert Scale. There are 34 questions to measure Power Distance, Individualism vs. Collectivity, Masculinity vs. Femininity, Uncertainty Avoidance, Long-term orientation vs. Short-term orientation, and Indulgence vs. Restraint. Thus, the VSM (value survey module) developed by Hofstede was used in were used in calculating cultural dimension scores as the Analysis techniques.

\section{RESULTS AND DISCUSSION}

\section{RESULT}

This research was conducted in Badung Regency, Bali Province. As a tourist destination Badung Regency was formerly famous for its tourist destinations Kuta, ITDC Nusa Dua Jimbaran area, Plaga, Canggu, and Seseh. The hotels whose employees are respondents in this area are: 
Table 4.1

\section{Region}

Badung Regency

\section{Respondent Profile Hotel's name}

Hotel Neo+ Kuta, Legian
Permata Kuta Hotel
Favehotel Kuta Kartika Plaza
Grand Mega Resort \& Spa
Grandmas Plus Hotel Airport
Max One Hotel, Jimbaran
Kutabex, Jimbaran
Total

\section{Number of respondent} (person)

18

20

25

22

10

20

20

135

Respondents to this study were star hotels taken from different departments in 7 different hotels.

The profiles of respondents could be seen as follows:

Table 4.2

Respondent Profile

\begin{tabular}{|l|l|l|l|}
\hline No & \multicolumn{2}{|c|}{ Respondent Profile } & Seminyak \\
\hline 1 & Total Respondent & 135 \\
\hline 2 & Gender & Male & 99 \\
\cline { 3 - 4 } & & female & 36 \\
\hline 3 & \multirow{3}{*}{ Age Range } & $<20$ years old & 0 \\
\cline { 3 - 4 } & & $20-24$ years old & 25 \\
\cline { 3 - 4 } & & $25-29$ years old & 40 \\
\hline \multirow{n}{*}{} & $30-34$ years old & 32 \\
\hline & $35-39$ years old & 35 \\
\hline & & $40-49$ years old & 3 \\
\hline
\end{tabular}

The calculation of the cultural value score of star hotels in Badung Regency is performed using the formula of calculating the Value Survey Mudule (VSM) 2013 index set by Hofstede. The formula used to calculate the index of 4 (four) cultural dimensions is as follows:

Table 4.3

Index Calculation Formula

\begin{tabular}{|l|l|l|}
\hline No & Cultural Dimension & Index Calculation Formula \\
\hline 1 & Power Distance Index (PDI) & $35(\mathrm{~m} 07-\mathrm{m} 02)+25(\mathrm{~m} 20-\mathrm{m} 23)+\mathrm{C}(\mathrm{pd})$ \\
\hline 2 & Individualism vs Collectivism (IDV) & $35(\mathrm{~m} 04-\mathrm{m} 01)+35(\mathrm{~m} 09-\mathrm{m} 06)+\mathrm{C}(\mathrm{ic})$ \\
\hline 3 & Mascullinity vs Feminity (MAS) & $35(\mathrm{~m} 05-\mathrm{m} 03)+35(\mathrm{~m} 08-\mathrm{m} 10)+\mathrm{C}(\mathrm{mf})$ \\
\hline 4 & Uncertainty Avoidance (UAI) & $40(\mathrm{~m} 18-\mathrm{m} 15)+25(\mathrm{~m} 21-\mathrm{m} 24)+\mathrm{C}(\mathrm{ua})$ \\
\hline
\end{tabular}


Hereby, the index calculation from each cultural dimensions are grouped as follows:

Table 4.4

Cultural Dimension Scale by Hofstede

No Dimension Range Score Results

$\begin{array}{llll}1 & \text { PDI } & 0-50 & \text { Small } \\ & & 50-110 & \text { Large } \\ 2 \quad \text { IDV } & 5-50 & \text { Collectivism } \\ & & 50-95 & \text { Individualism } \\ & \text { MAS } & 5-50 & \text { Feminism } \\ & & 50-95 & \text { Maskuline } \\ & \text { UAI } & 5-60 & \text { Weak } \\ & & 60-115 & \text { Strong }\end{array}$

Based on the formula used for calculating the index and the set range of scores, the results of calculating the cultural dimensions of star hotels in Badung Regency could be seen as follows: 
Table 4.5

\section{Respond Assessment Recapitulation of stars Hotel}

\begin{tabular}{|c|c|c|c|c|c|c|c|c|}
\hline \multirow{2}{*}{ Questions } & \multicolumn{5}{|c|}{ Score } & \multirow{2}{*}{ Qty 1} & \multirow{2}{*}{ Qty 2} & \multirow{2}{*}{ Avr } \\
\hline & 1 & 2 & 3 & 4 & 5 & & & \\
\hline No 1 & 93 & 71 & 76 & 0 & 0 & 240 & 463 & 10,2889 \\
\hline No.2 & 106 & 70 & 53 & 11 & 0 & 240 & 449 & 9,97778 \\
\hline No 3 & 119 & 92 & 28 & 1 & 0 & 240 & 391 & 8,68889 \\
\hline No 4 & 103 & 30 & 90 & 15 & 2 & 240 & 503 & 11,1778 \\
\hline No 5 & 120 & 101 & 19 & 0 & 0 & 240 & 379 & 8,42222 \\
\hline No 6 & 107 & 101 & 31 & 0 & 1 & 240 & 407 & 9,04444 \\
\hline No 7 & 93 & 92 & 49 & 6 & 0 & 240 & 448 & 9,95556 \\
\hline No 8 & 106 & 102 & 32 & 0 & 0 & 240 & 406 & 9,02222 \\
\hline No 9 & 144 & 69 & 25 & 2 & 0 & 240 & 365 & 8,11111 \\
\hline No 10 & 109 & 99 & 30 & 1 & 1 & 240 & 406 & 9,02222 \\
\hline No 11 & 78 & 65 & 88 & 9 & 0 & 240 & 508 & 11,2889 \\
\hline No 12 & 121 & 32 & 81 & 5 & 1 & 240 & 453 & 10,0667 \\
\hline No 13 & 16 & 88 & 123 & 5 & 8 & 240 & 621 & 13,8 \\
\hline No 14 & 99 & 98 & 33 & 3 & 7 & 240 & 441 & 9,8 \\
\hline No 15 & 0 & 69 & 38 & 122 & 11 & 240 & 795 & 17,6667 \\
\hline No 16 & 112 & 104 & 22 & 2 & 0 & 240 & 394 & 8,75556 \\
\hline No 17 & 38 & 116 & 56 & 30 & 0 & 240 & 558 & 12,4 \\
\hline No 18 & 27 & 35 & 16 & 63 & 99 & 240 & 892 & 19,8222 \\
\hline No 19 & 118 & 18 & 72 & 9 & 23 & 240 & 521 & 11,5778 \\
\hline No 20 & 5 & 102 & 21 & 104 & 8 & 240 & 728 & 16,1778 \\
\hline No 21 & 34 & 83 & 26 & 93 & 4 & 240 & 670 & 14,8889 \\
\hline No 22 & 30 & 84 & 0 & 41 & 85 & 240 & 787 & 17,4889 \\
\hline No 23 & 8 & 86 & 29 & 91 & 26 & 240 & 761 & 16,9111 \\
\hline No 24 & 3 & 13 & 104 & 115 & 5 & 240 & 826 & 18,3556 \\
\hline
\end{tabular}

\section{DISCUSSION}

From the results of a survey conducted on star hotels in Badung Regency, it has a cultural value of Individualism VS Collectivism of 48 (forty eight) from a range of values of 0 to 50. This means that Badung regency's star hotels have a culture with a high level of collectivism. It also proves that star hotels in this area have a culture of togetherness and compactness (collectivism).

Star hotels in this area are proven to still hold the local wisdom called "menyama braya". The concept of "menyama braya" is a concept of community life in Bali that is derived from the system of cultural values and customs of local people to be able to live together. The value of local wisdom "menyama braya" means togetherness, brotherhood and social recognition that we are brothers.

The star hotel in Badung Regency has a score of 30 (thirty). This score shows a low power distance value. This means that the relationship between superiors and subordinates at hotels in Bali is quite close. Hotel leaders are respected not solely for their position, but for their democratic leadership style. Cultural values where the distance of power in star hotels in Badung Regency is low shows that democracy and mutual respect between superiors and subordinates 
become the culture of star hotels in this area. Related to the culture of democracy, star hotels in this area apply the values of local Balinese wisdom, some of them: tat twam asi (tolerance without accentuating differences); paras paros (giving and receiving each other's opinions); merakpak danyuh or dissent does not eliminate friendship.

Star hotels in Badung Regency have a score of 40 (forty) from a range of 0 to 50. This score indicates that star hotels in this area tend to have Feminine culture. This shows that star hotel employees have their motivation not because they want to be the best (masculinity), but rather their work motivation arises because star hotels in Bali like what they are doing (feminine). The score also shows that most star hotels work not perform any competion.

The culture seen in star hotels in this area that have low scores for budaya (feminine) means they have a high preference for quality of life and attention to other individuals (social life). The low value of masculinity in star hotels in this area shows the value of Balinese culture in the concept of Jengah (a strong push from yourself to make changes) is not fully owned by star hotels in Badung Regency.

From the calculation of the results of the questionnaire conducted, the cultural value of Uncertainty Avoidance star hotels in Badung Regency is 49 (fortynine). This shows that star hotels in Badung Regency have a culture with a relatively low level of Uncertainty Avoidance. This score shows that star hotels in this area do not so in frighten of anything uncertain or ambiguous and like new and different ideas and concepts than usual.

Star hotels that have low uncertainty avoidance have the characteristic of frequent innovations because for them something new is not feared and must be conducted.

\section{CONCLUSION}

Based on the discussion of the research results in Chapter IV, it can be concluded as follows: The description of the application of local wisdom value in star hotels in Badung Regency from 6 dimensions is practiced as follows:

Badung regency has a culture with a fairly high level of collectivism. It also proves that star hotels in this area have a culture of togetherness and compactness (collectivism). The form of employees in star hotels who work is proven to still hold local wisdom called "menyama braya". Hotel workers show low power distance value. This means that the relationship between superiors and subordinates at star hotels in Badung district is quite close. Hotel leaders are respected not solely for their position, but because of their leadership style. Star hotel workers tend to have a Feminine culture, which shows that star hotel employees have their motivation arise not because they want to be the best (masculinity), but rather work motivation likes what they are doing (feminine). They do not work to compete each other. Hotel workers show a relatively low level of uncertainty avoidance. This score shows that star hotels in this area are not so afraid of anything uncertain or ambiguous and like new and different ideas and concepts than usual.

The positive impacts of applying local wisdom values to employees in star hotels in Badung Regency could be concluded as follows:

The concept of "menyama braya" is a concept of community life in Bali that is 
derived from the system of cultural values and customs of the local people. Application of tat twam asi (tolerance without accentuating differences); paras paros (giving and receiving each other's opinions); merakpak danyuh or dissent does not eliminate togetherness.

Related to the overall content of this research, there are several input could be suggested as follows:

1. To the Balinese tourism observer community, it should be explored further about the culture of the organization that able to elevate the quality of product development (service) in accordance with the positive local culture.

2. Academics and practitioners should be able to make a guideline that contains the organizational culture in accordance with the positive local culture to provide a deep understanding, both to the community and tourists of various parties feel positive benefits.

3. The star hotels should further socialize local values that are useful and beneficial to workers, so that, when providing services the peculiarities of service will be differentiation and positioning service. It is important to change the paradigm of lay people that tourism is presented not as a multifaceted cultural degradation into secular, but rather strengthen the existence of Balinese culture.

\section{REFERENCES}

Bearden. 2006. Multidimensional versus unidimensional measures in assessing national culture values: The Hofstede VSM 94 example. Journal of Business Research. 59 (2006) 195-203

Creswell, John W. 2015. Penelitian Kualitatif \& Desain. Riset.Yogyakarta: Pustaka Pelajar

https://bali.bps.go.id/statictable/2018/02/09/21/jumlah-wisatawan-asing-ke-balimenurut-bulan-1982-2019.html diakses pada tanggal (5 Juni 2020)

Huang, Songshan (Sam) \& Crotts, John. 2019. Relationships between Hofstede's cultural dimensions and tourist satisfaction: A cross-country cross-sample examination. Tourism Management. 72 (2019) 232-241

Evans, N Campbell, D and Stonehouse, G. 2003. Strategic Management for Travel and. Tourism. Oxford: Butterworth-Heineman.

Hofstede, Geert. 2010. Comparing Regional Cultures Within a Country: Lessons From Brazil. Jounal of Cross-Cultural Psychology; 41;336.

Hofstede, Geert. 2010. Culture and Organizations: Software of the Mind, International Cooperation and its Importance For Survival. New York: McGraw-Hill.

Mazanec, Josef A .2015. Homogeneity versus heterogeneity of cultural values: An item-response theoretical approach applying Hofstede's cultural dimensions in a single nation. Tourism Management. 48 (2015) 299-304

Sugiyono, 2020. Metode Penelitian Pariwisata. Bandung: Alfabeta. 